\title{
Duress as a Tort Law Defence?
}

\author{
John Murphy*
}

\begin{abstract}
This article addresses a straightforward question: "Should tort law recognise a defence of duress?" Previous scholarship concerning this issue is thin on the ground; and the answers it supplies are demonstrably inadequate. Those who have favoured the development of a duress defence in tort have done so by analogy with criminal law where duress is, of course, well established. The rival school of thought has sought to highlight the fact that excuse defences are out of place in tort and that, therefore, there is no room for duress in tort. This article rejects both approaches. It accepts that the criminal law is a poor source of analogy, but rejects the idea that duress must be seen as an excuse (and hence the idea that there can be no space for it in tort). It offers a fresh start based on the role of duress within tort law's sibling, the law of contract. It identifies three possible conceptions of duress in contract and then asks whether these conceptions could be used to ground a comparable defence of duress in tort by analogy. It concludes that a plausible case can be made in respect of each conception, but - given that the paper has primarily theoretical ambitions - it stops short of advocating any one conception in particular.
\end{abstract}

\section{Introduction}

In recent years, tort law defences have begun to receive a fair amount of academic attention. The most comprehensive exploration of this subject to date belongs to James Goudkamp who, in a pioneering monograph, claims that tort defences seem generally to have been regarded as "a peripheral part of tort law that is undeserving of serious consideration". "Although this is something of an overstatement - since most decent textbooks provide extensive coverage of the many defences available in defamation and nuisance, as well as of the more general defences of consent and illegality - it is certainly the case that the task of classifying and justifying tort defences as a whole seems never really to have captured the attention of jurists in the past.

Of course, it is true that certain, individual defences have received limited scholarly attention from time to time. ${ }^{2}$ But it is equally true that the amount of juristic attention devoted to tort defences is dwarfed by the equivalent body of work within criminal law where defences have been analyzed at great length, by many, for decades. ${ }^{3}$ And while interest in certain tort defences is now growing, there are still many of the well-known ones that continue to dip below most scholars' radars. Beyond these, there are several further possible defences that also deserve consideration: ones we do not presently recognise but in respect of which a claim for recognition

\footnotetext{
* Lancaster University. Pour Anne-Claire Goyallon qui plus que quiconque m’a récemment aidé à reconnaître ce qui vaut vraiment la peine d'être appris. Thanks to David Campbell, Peter Chau, John Goldberg, James Goudkamp, Luisna Ho and David Howarth for their helpful comments on various drafts. The usual caveat applies.

${ }^{1} \mathrm{~J}$ Goudkamp, Tort Law Defences (Oxford: Hart Publishing, 2013) 7.

2 See, eg, R O’Dair, “Justifying an Interference with Contractual Rights” (1991) 11 OJLS 227; J Murphy, "Rethinking Tortious Immunity for Judicial Acts” (2013) 33 LS 455.

${ }^{3}$ See, inter multos alios, J Horder, Excusing Crime (Oxford: OUP, 2004) and J Gardner, Offences and Defences: Selected Essays in the Philosophy of Criminal Law (Oxford: OUP, 2007).
} 
can ostensibly be made on the strength of their presence in other areas of the law with which tort law shares certain commonalities. ${ }^{4}$ At least three defences fit this description. They are loss of control, infancy and duress.

This article considers only the last of these, and its central question is this: $\underline{\text { Can a }}$ respectable theoretical case be made for tort law to recognise a defence of duress $?^{\frac{5}{5}}$ The article unfolds as follows. In section 2, I define three key terms that are used throughout the paper. In section 3, I examine and find wanting the limited existing scholarship on this subject. In section $\underline{4}$ - having concluded that no-one has thus far made a convincing case one way or the other - I offer a fresh approach to the central question of whether a duress defence should be recognised in tort. Unlike those who have sought to make the case for such recognition by placing analogical weight on a series of perceived commonalities between criminal law (where duress is well established) and tort law, I explore the possibility that contract law (where duress is equally well entrenched) may provide a better guide. Section 5 offers some tentative conclusions.

\section{(2) Three Key Terms}

For clarity's sake, it is useful to state from the outset what is meant by three key terms used throughout this article. They are justification, excuse and denial. ${ }^{6}$ Justifications and excuses are both defences in the strict sense, but they need to be distinguished from each other. With excuses, defendants offer reasons for wrongful conduct that enable courts to empathise with (and forgive) their wrongful behaviour. They are not, however, good enough reasons for courts to consider the conduct in question to be rightful. They involve rational but not reasonable conduct. A justification different. The explanation given for a justification shows the conduct in question to have been entirely reasonable. As Kent Greenawalt put it: "If A's claim is that what he did was fully warranted... A offers a justification" whereas "if A acknowledges that he acted wrongfully but claims he was not to blame... he offers an excuse". ${ }^{7}$ Most theorists seem broadly to agree. ${ }^{8}$

Denials are very different. They are not defences strictly speaking. They are assertions that a particular ingredient of a tort is absent. For example, one puts forward a denial if one

\footnotetext{
${ }^{4}$ J Goudkamp, "Insanity as a Tort Defence" (2011) 31 OJLS 727.

5 Since the wrongs performed under duress are intentional wrongs, it follows that duress in tort law must be confined to the intentional torts.

6 The sketch offered here adopts the typology in Goudkamp (n 1). Those with whose work this article principally engages both acknowledge and do not reject this categorisation (though see also (n 39) below).

7 K Greenawalt, "The Perplexing Borders of Justification and Excuse" (1984) 84 Columbia LR 1897, 1897.

8 See, eg, A Ripstein, Equality, Responsibility and the Law (Cambridge: CUP, 1999) 138-9; Goudkamp (n 1) 86; Goldberg (n 12) 472 .
} 
pleads inevitable accident in the context of a negligence action, for one denies that the fault element is satisfied. ${ }^{?}$

\section{(3) The Inadequacy of the Arguments to Date}

The only paper so far to have concerned itself exclusively with the question of whether duress should be recognised as an English tort defence was written by James Edelman and Esther Dyer. ${ }^{10}$ For them, four considerations combine to make a case in favour of its adoption. ${ }^{11}$ First, they say, existing English authority which obstructs such recognition can be sidelined on the footing that it is ancient, intrinsically weak, and contrary to United States authority. Secondly, they argue that a defence of duress in tort can be crafted by analogy with criminal law on the basis of a series of perceived parallels between the two branches of law. Thirdly, they contend that private necessity is a recognised tort defence and that, since there exists just a wafer-thin distinction between duress and private necessity, it makes little sense to exclude the former but accept the latter as a defence. Finally, they suggest that several putative arguments of principle against the recognition of duress in tort law can be set aside because they rest on flawed premises.

Though perhaps superficially attractive, these considerations are not sufficiently compelling, either alone or in combination, to ground tort law's acceptance of this defence. Some key weaknesses in the Edelman and Dyer thesis have already been highlighted by John Goldberg writing in the self-same collection of essays. ${ }^{12}$ However, because Goldberg does not attend comprehensively to their arguments, and because there are other objections to their account that are worth stressing, it is worthwhile our examining the various strands to their argument, and the weaknesses they contain.

The first point made by Edelman and Dyer is that we should dismiss the existing English authority which stands in the way of a duress defence in tort. They give three reasons for so thinking. The obstructive authority, they say, is limited, inherently weak and contradicted by case law from the United States.

Certainly, Edelman and Dyer are right to point out that there is a more-or-less solitary obstructive authority. It is the $17^{\text {th }}$ century case of Gilbert $v$ Stone ${ }^{13}$ in which 12 armed men threatened to kill the defendant unless he trespassed on the claimant's land and stole his horse.

\footnotetext{
9 Browne v De Luxe Car Services [1941] 1 KB 549, at 552. It is possibly also a denial of the causation element.

${ }^{10} \mathrm{~J}$ Edelman and E Dyer, "A Defence of Duress in the Law of Torts?" in A Dyson et al (eds), Defences in Tort (Oxford: Hart, 2015).

${ }^{11}$ The four considerations are enumerated ibid at pp 161-162.

${ }^{12}$ JCP Goldberg, “Tort Law's Missing Excuses” in A Dyson et al (n 10).

13 (1647) Style 72; 82 ER 539.
} 
In defence of Gilbert $v$ Stone, John Goldberg argues that "there is nothing particularly odd about tracing settled common law rules to a single decision". ${ }^{14}$ He cites Weaver $v W$ ard ${ }^{15}$ and Vaughan $v$ Menlove $^{16}$ as examples of similarly ancient cases that ground established rules of law. Indeed, he sees Vaughan as especially pertinent because it exhibits (so he says) a clear refusal on the part of tort law to excuse a defendant who acted to the best of his personal capacities when it comes to applying the reasonably prudent person standard in negligence. It reinforces, he claims, the idea that Gilbert v Stone is not really anomalous but merely part of a broader tapestry of "inexcusable wrongs". ${ }^{17}$

Goldberg is right that certain, landmark cases can ground settled rules of law. Lumley $v$ $G y e^{18}$ and Mogul Steamship Co v McGregor ${ }^{19}$ (in which the torts of inducing breach of contract and simple conspiracy were first minted) would be other notable examples. Yet his second point that Vaughan helps to substantiate the claim that torts are generally inexcusable - is assuredly wrong. The argument in Vaughan was essentially that a defendant with limited capacity should be handled more charitably when it comes to setting the standard of care. This involved a denial rather than an excuse, for it was an invitation for the court to hold that the breach element in the action was absent. It is as if the defendant were saying: "I should not be judged to have acted below the standard of care demanded by the law, since the standard of care required of someone with my limited faculties is a very low one".

Nor does Goldberg's first point - that certain landmark cases can ground settled rules of law -win him the argument that Gilbert $v$ Stone should be respected. This is because he pays no attention to the two additional point concerning Gilbert $v$ Stone made by Edelman and Dyer. The first of these, recall, is that Gilbert $v$ Stone is so flawed a decision that it ought not to be treated as authoritative on the matter of whether a duress defence exists in tort. The second, normative in nature, is that, because Gilbert $v$ Stone is irreconcilable with subsequent United States authority, it ought no longer to be followed. Both these objections must be rebuffed before any serious defence of Gilbert v Stone can be offered.

On the claim that it is an intrinsically a weak authority, Edelman and Dyer make much of the fact that the case rests upon a false premise. Their objection to Gilbert $v$ Stone on this front is wholly warranted. Recall again the facts: the armed men threatened to kill Stone unless he trespassed on Gilbert's land and stole Gilbert's horse. Stone succumbed to the threat and was

\footnotetext{
14 Goldberg (n 12) 58.

15 (1616) Hob 134.

16 (1837) Bing NC 468.

${ }_{17}$ Goldberg (n 12) 58.

18 (1853) 2 E\&B 216.

19 [1892] AC 25.
} 
subsequently sued for trespass by Gilbert. Roll J held that a person "may not do a trespasse to one for fear of threatenings of another, for by this means the party injured shall have no satisfaction, for he cannot have it of the party that threatened". ${ }^{20}$ In modern language: Stone had to be denied a defence because Gilbert would otherwise have had no remedy available to him. This is wrong. A potential remedy was available to Gilbert from those making the threat. In Garret v Taylor, ${ }^{21}$ decided some decades earlier, it had been established that X can sue $\mathrm{Y}$ in tort where $\mathrm{Y}$ has coerced $\mathrm{Z}$ into acting in a way that causes loss to $\mathrm{X}$.

Given this flaw in Roll J's reasoning, and given also the existence of clear, countervailing, subsequent United States authority, ${ }^{22}$ Goldberg seems rather too comfortable with his only valid point in defence of Gilbert $v$ Stone: the fact that isolated, ancient cases sometimes ground settled rules of law. ${ }^{23}$ He certainly overlooks the equally valid point that solitary decisions can lose their precedential status through a combination of the effluxion of time and the absence of repeated application in subsequent cases. ${ }^{24}$ So, even if the decision in Gilbert $v$ Stone did once ground the proposition that tort law does not permit a defence of duress, ${ }^{25}$ it can perfectly well be questioned whether it does so today.

However feeble the authority of Gilbert $v$ Stone, it by no means follows that we must accept the Edelman and Dyer thesis that a duress defence should be allowed in tort. At most, Edelman and Dyer succeed in providing no more than a couple of reasons to doubt whether Gilbert v Stone is really a very formidable obstacle to such a development. Yet removal of the obstacle should not be mistaken for an argument in favour of a duress defence in tort. If we are to add a defence of duress to tort law, we need positive reasons for so doing, and not merely the absence of objections.

Edelman and Dyer suggest that one such positive reason inheres in an analogy that may be drawn with the criminal law. They put it this way: "indirect support for the recognition of a defence of duress to tortious liability can be found by extending the application of the defence of duress as it is recognised in the criminal law". ${ }^{26}$ In their favour, perhaps, is the fact that there exist numerous crimes that have equivalents among the intentional torts_(which, as noted earlier,

\footnotetext{
20 (1647) Style 72; 82 ER 539, at 539.

21 (1620) Cro Jac 567.

22 Waller v Parker 45 Tenn 476 (1878) permitted a duress plea in tort: see further Goudkamp (n 1) 89.

23 See Goldberg (n 12) 59.

${ }^{24}$ For a full defence of the contention that "more often than not, the authority of a precedent will diminish rather than ripen with age", and for details of others - including judges - who support it, see N Duxbury, The Nature and Authority of Precedent (Cambridge: CUP, 2008) 63 et seq.

${ }^{25}$ It is very possible that Edelman and Dyer, Goldberg and Goudkamp - all of whom treat the case as having said this - have misinterpreted Gilbert $v$ Stone. What Roll J actually said, according to the fuller report of the case was that "one cannot justifie a trespass upon another for fear": (1641) Aleyn 35, 35. Thus, he may have been saying no more than that duress is no basis upon which to substantiate the well-established defence of justification of trespass.

${ }^{26}$ Edelman and Dyer (n 10) 162.
} 
would be the natural home for a duress defence in $\operatorname{tort}_{-}^{27}$. The criminal lawyer's assault is the tort lawyer's battery; the criminal lawyer's theft is the tort lawyer's conversion; the criminal lawyer's fraud is the tort lawyer's deceit. Mindful of these parallels, Edelman and Dyer suggest that because "[t]ortious liability for exerting unlawful pressure upon another (intimidation)... developed by reference to the criminal liability for such pressure (menaces)" we should take the next logical step and "introduce a defence of unlawful pressure by reference to the criminal defence [of duress]". ${ }^{28}$

Of course, whether there is much merit in this argument depends ultimately on how close a connection there really is between criminal law and tort. ${ }^{29}$ In his rebuttal of Edelman and Dyer on this front, Goldberg offers the observation that "tort and criminal law involve distinctive notions of wrongdoing and responsibility" such that there is, in truth, "no more reason to incorporate criminal law's duress defence into tort law than there is to incorporate tort notions of fault into contract law". ${ }^{30}$ It is a strong point and one that Goldberg has elaborated elsewhere along two main lines. ${ }^{31}$ The first of these stresses the fact that criminal law insists on "capacity and control conditions" 32 which serve to ensure the moral blameworthiness of the criminal defendant whereas tort law is overwhelmingly "keyed to outcomes even given the tortfeasor's lack of substantial control over those outcomes". ${ }^{33}$ Goldberg is right. The mens rea requirement certainly does occupy a central position within the criminal law while strict liability which is obviously attentive to outcomes rather than culpability - is by no means a rare phenomenon within tort law.

Goldberg's second fundamental difference between crime and tort emphasises the fact that the former involves unilateral considerations while those which characterise tort are bilateral in nature. Put more simply: in criminal law, the only individual whose interests are at stake is the defendant, whereas in tort the court must weigh the interests of both claimant and defendant equally. The key question in tort is not whether the state should punish the wrongdoer on behalf of the public or excuse him (as in crime), but whether the claimant, who has been wronged, should have an avenue of civil recourse against the defendant. ${ }^{34}$ It is this difference, says Goldberg, that explains why excuses can be accommodated within criminal law, and why they

\footnotetext{
27 See $n 5$ above.

28 Ibid, 165.

${ }^{29}$ I accept arguendo the assumption made by Edelman and Dyer that it is tort law rather than the criminal law that ought to change. But one could just as easily invert the "logic" and argue that the criminal law should abandon the duress defence in order to align itself with tort.

30 Goldberg (n 12) 59.

${ }^{31}$ JCP Goldberg, "Inexcusable Wrongs" (2015) 103 California L Rev 467, 500-505.

32 Ibid, 501.

33 Ibid, 503. My Italics.

${ }^{34}$ Goldberg's work on civil recourse theory is voluminous. But a sufficient account of his general position can be found in JCP Goldberg and BC Zipursky, “Torts as Wrongs” (2010) 88 Tex L Rev 917.
} 
are alien to tort law. Just because excuses make sense when tested against the raison d'etre of the criminal law does not mean that they can simply be rolled out by analogy in tort where questions of blame, culpability, and deservingness of punishment at the hands of the state are not at issue. ${ }^{35}$

Almost certainly, Goldberg proffers the stronger arguments on this issue. And yet it is important to realise that all that he really manages to show is that there is good reason to pause and consider before making duress a tort defence. Showing that something is more naturally at home in one context than in another is by no means the same thing as showing that the thing in question has no place at all in the second context. Take, for example, punishment. The fact that punishment is, like mens rea, a central plank of the criminal law does not lead inexorably to the conclusion that it has no role whatever to play in tort law. Indeed, without ever being the norm, tort law provides awards of punitive damages in most common law jurisdictions. ${ }^{36}$ Similarly, the although duties based on the voluntary assumption of a responsibility are naturally at home in the contract setting, they are by no means alien to tort law (even though tort duties are ordinarily imposed by virtue of pre-existing rules of law). ${ }^{37}$

A second limit to Goldberg's argument inheres in the fact that, in the course of his attempt to show why excuses do not belong in tort law, he more or less assumes that duress is an excuse and not some other kind of defence. ${ }^{38}$ So, even if he succeeds in showing that excuses have no place in tort, he has must do a great deal more to show conclusively that duress has no place in tort. His arguments against Edelman and Dyer have traction only so long as duress is conceived as an excuse; but not if (as Edelman and Dyer in fact contend) it can be seen as a different type of defence. ${ }^{39}$

On the other hand, Goldberg's weaknesses cannot be taken to imply strength in the Edelman and Dyer account since that too is flawed in its analogy with the criminal law.

In a recent essay, James Goudkamp unearthed several important ways in which the defences in tort and criminal law diverge. ${ }^{40}$ His having done so renders highly dubious the Edelman and Dyer analogy. For what emerges from Goudkamp's essay is the fact that, when it comes to defences, the two domains are very different indeed. They are so different, in fact, that

\footnotetext{
35 Cf P Cane, "Mens Rea in tort law" (2000) 20 OJLS 533.

36 A similar argument, couched in terms of retributive justice, is marshalled in J Goudkamp, "Defences in Tort and Crime" in M Dyson (ed), Unravelling Tort and Crime (Cambridge: CUP, 2014) 225.

${ }^{37}$ See, eg, the long line of cases stemming from Hedley Byrne v Heller [1964] AC 465.

38 There is, admittedly, fleeting acknowledgement of the idea that duress may, very occasionally, function as a denial or a justification (Goldberg (n 31) 475-6). But Goldberg sees such cases as being very rare.

39 They recommend an approach that is "independent of the terminology of excuse and justification" and which treats duress "as a privilege": Edelman and Dyer (n 10) 181.

${ }^{40}$ Goudkamp (n 36) 208.
} 
the distinctions far outweigh the commonalities. ${ }^{41}$ True, Goudkamp stops short of showing that certain defences presently found in criminal law are necessarily out of place in tort. But the sheer number and importance of the differences between the two defence regimes to which Goudkamp alludes certainly place in doubt the idea that we should ever feel comfortable about creating new defences in tort law by analogy with those found in criminal law.

In his discussion of duress specifically, Goudkamp highlights one especially significant difference between tort and criminal law which speaks against the idea that what holds for the one should hold, also, for the other. It is that in the context of tort, where the litigants are treated as equals, there arises an obstacle to recognising duress qua excuse. It is the fact that "there is no reason to prefer one morally innocent person over another". ${ }^{42}$ If $\mathrm{C}$ is just as morally innocent as $\mathrm{D}$, then there is no good reason why, in tor, we should require $\mathrm{C}$ to bear the losses caused by D's tort. By contrast, within the criminal law, no such contest between morally equal individuals need be considered.

But even Goudkamp's point does not provide a definitive answer. This is because it will not always be the case in tort that there will be a toss-up between two moral equals. In cases with facts similar to Gilbert $v$ Stone, the tort of causing loss by unlawful means might be available. Thus, giving $\mathrm{D}$ a defence needn't necessarily mean that $\mathrm{C}$ will bear the loss: $\mathrm{C}$ could instead sue the third party who threatened D. ${ }^{43}$ Equally, if the duress defence were considered a public policy defence (rather than an excuse), the moral equivalence of $\mathrm{C}$ and $\mathrm{D}$ would be an irrelevance. The only relevant consideration to $\mathrm{D}$ claiming the defence would be whether the particular public policy considerations that ground the defence were met.

The third plank of Edelman and Dyer's thesis rests heavily on the twin claims that private necessity is a recognised tort defence, and that there is little to distinguish duress from private necessity. In making these observations, they see a case for the recognition of a duress defence in tort that runs thus: since we already have the first of these defences, we ought also to have the other given the paper thin distinction between them.

\footnotetext{
41 Among the differences highlighted by Goudkamp are: (1) the respective rules on self-defence are very different; (2) criminal law alone contains partial defences which exonerate D from one crime but permit conviction for another; (3) criminal law embraces a defence of private necessity whereas tort law seems not to do so; (4) the rules on who can raise a defence differ as between crime and tort.

${ }^{42}$ Goudkamp (n 36) 230. This amounts to a slightly clearer iteration of the point made by Goldberg that the interests of two parties are at stake in tort cases (unlike in criminal law where D is the only individual whose interests are in play).

${ }^{43} \mathrm{~A}$ possible rejoinder here is that it may be harder for $\mathrm{C}$ to trace threat maker than it is than to sue D. However, tort law's rules are overwhelmingly designed to pinpoint the right person to sue, and not simply the easiest. (One possible exception is the vicarious liability principle.)
} 
As regards the first claim, Edelman and Dyer anchor their contention that private necessity is an extant tort defence to the decision in Cope v Sharpe (No 2). ${ }^{44}$ It is certainly true that two out of the three judgments supplied by the Court of Appeal in that case support this interpretation. ${ }^{45}$ Accordingly, Goldberg's tentatively expressed alternative reading - that this case "arguably rests on the ground that the defendant was exercising rights that had been conferred on him by the lease, rather than on a claim of necessity" ${ }^{46}$ - warrants a sceptical reception. However, the simple fact that Edelman and Dyer can probably withstand Goldberg's suggestion that they adopt the wrong interpretation of Cope v Sharpe (No 2) does not mean, once again, that their claim about the place of private necessity in tort is altogether sound. This is because the majority view in Cope v Sharpe (No 2) is clearly contradicted by the subsequent, famous decision in Vincent $v$ Lake Eerie Transportation Co ${ }^{47}$ In that case, the idea that private necessity could constitute a defence was rejected by the Supreme Court of Minnesota.

One could, of course, argue that contradictory American authority is not a cast iron reason to doubt the correctness of Cope v Sharpe (No 2). Yet on the other hand, one cannot but recall the fact that Edelman and Dyer themselves regard subsequent American authority as a reason for doubting the soundness of Gilbert $v$ Stone. If one prior English case should be doubted in the light of countervailing, subsequent authority from an appeal court in a fellow common law jurisdiction, why not the other? One cannot both accept and deny the capacity of such decisions to cast serious doubt over domestic decisions; especially where those domestic decisions lack repeated endorsement in subsequent cases. And, on this front, the lack of subsequent endorsement is as true of Cope v Sharpe (No 2) as it is of Gilbert v Stone. ${ }^{48}$

Given, then, the fragility of the claim that private necessity is an established tort defence, we must treat with caution the claim that duress ought to be recognised as a tort defence on the basis that there is a wafer-thin distinction between duress and private necessity. This third strand to Edelman and Dyer's thesis, in other words, does as little to convince us that duress should be a tort defence as each of their other two arguments so far considered. It places far too much weight on a highly contentious claim over which academic and judicial views divide sharply. ${ }^{49}$ Furthermore, their argument could simply be turned on its head. One could just as easily say:

\footnotetext{
44 [1912] 1 KB 496.

${ }^{45} \mathrm{Ibid}$, at 503 and 504-5, per Vaughan Williams and Buckley LJ.

${ }^{46}$ Goldberg (n 12) 61 (emphasis added). This interpretation draws on a single, slightly unclear passage in the judgment of Kennedy LJ.

47109 Minn 465. The decision, though rejected in some US jurisdictions, is nonetheless endorsed in the Restatement (Second) of Torts torts $\int 197$. As to why private necessity may never be a tort defence, see Goudkamp (n 36) 212-3.

${ }_{48}$ Gillbert v Stone received a nod of approval in the dissenting judgment of Blackstone J in Scott v Shepherd (1773) 2 Black W 892, at 896, while the decision in Cope v Sharpe (No 2) was approved, but only obiter, by Lord Goff in Re F (Mental Patient: Sterilisation) [1990] 2 AC 1, at 74.

${ }^{49}$ See, eg, G Virgo, "Justifying Necessity as Defence in tort Law" in Dyson et al (n 10). Cf Goldberg (n 12); Goudkamp (n 36) 215.
} 
"Given that duress is not a recognised tort defence, and given that there is but a wafer thin distinction between duress and private necessity, it follows that private necessity has no rightful place in tort law". They offer no argument against this approach.

The final strand to the Edelman and Dyer thesis posits that several putative arguments of principle against the recognition of duress in tort law can be dismissed because they rest on flawed foundations. One such objection that they suggest is that a duress defence would be inconsistent with the fundamental goal of tort law to ensure the provision of compensation to tort victims from tortfeasors who have harmed them. However, as Edelman and Dyer point out, this objection fails because it is groundless. They point out that because some torts are actionable per se it must be clear that compensation is not the primary goal of tort law. Such torts, generally ancient in origin, are actionable regardless of any harm. Tort law, therefore, cannot be seen as being wholeheartedly (or even primarily) committed to a compensatory goal.

Edelman and Dyer also reject the argument that a duress defence can be opposed on the basis that it would constitute an unwarranted erosion of the claimant's rights. Ordinarily in tort, C's rights correlate to D's duties. D only needs a duress defence because a tort (ie, a breach of duty) has been committed. For there to have been a breach of duty, $\mathrm{C}$ must have held the relevant right. By definition, then, the defence of duress tends to confirm rather than erode those rights. The very invocation of the defence necessarily entails an admission that $\mathrm{C}$ holds the relevant right. For if $\mathrm{C}$ did not hold the relevant right, there would be no breach of duty to defend.

Nonetheless, the ability of Edelman and Dyer to fend off such putative arguments of principle is, once more, of only limited value to their overall project. Just as with their opposition to Gilbert v Stone (which only removes a potential obstacle to the recognition of duress), so, too, does their rebuttal of these supposedly principled objections achieve no more than a little path clearing. A compelling rejection of arguments against a duress defence must not be mistaken for a positive case in favour of its adoption.

Before considering what an alternative argument in favour of a tort defence of duress might look like, a brief summary here of the limitations of the scholarship to date is probably useful. Edelman and Dyer have gone to the greatest lengths thus far to establish a case for the recognition of a duress defence in tort. Their endeavour fails, however, for two main reasons. First, because some of the arguments they marshal are not really arguments in support of such a 
move: they are merely arguments designed to remove possible objections. Secondly, they place undue weight on analogies that highly dubious. Their claim that we should proceed by analogy with the criminal law is undermined by the numerous, significant differences between the defence regimes of these two branches of law. Equally, their suggestion that the development of a duress defence can be supported by reference to a supposed similarity between duress and private necessity is greatly weakened by the fact that there is but scant (and then contradicted) judicial support for the existence of a private necessity defence in tort.

By contrast, Goldberg is opposed to a defence of duress because he thinks that private law wrongs (unlike crimes) are inexcusable. The two main weaknesses with his position are (1) the fact that he more or less assumes that duress would have to function as an excuse, ${ }^{50}$ and (2) the fact that he pays inadequate attention to the role played by duress in tort's private law sibling, contract law.

\section{(4) Three Alternative Bases for a Tort Defence of Duress}

According to Goudkamp's taxonomy of tort law defences, there are two broad types of defence that are presently recognised by English tort law: justifications (such as self-defence, abatement and recapture of chattels) and public policy defences (such as public necessity, arrest and those contained in limitations statutes). ${ }^{51}$ Mindful of the fact that tort law happily accommodates these two types of defence, this section of the article will consider whether duress could conceivably operate in tort either under the banner of "justification" or that of "public policy defence". But it also considers a third possibility: whether, after all, a plausible case can be made for the recognition of duress in tort qua excuse by analogy with contract law.

In tackling these three possibilities, no further comparisons with the criminal law defence of duress will be made. The arguments against drawing such comparisons, rehearsed above, have been made convincingly by Goldberg and others. That said, just because Goldberg is on solid ground in rejecting analogies with the criminal law does not mean that he succeeds in his overall ambition to show that torts are inexcusable. The successful dismantling of argument $\mathrm{X}$ does not thereby entail or guarantee the success of rival argument $\mathrm{Y}$. To think that it does is to commit the error sometimes called the fallacy of the excluded middle. Furthermore, the mere fact that several scholars have thus far failed to make a convincing argument in favour of excuses generally

\footnotetext{
${ }^{50}$ Recall the point made earlier (above, $\mathrm{n} 25$ ) that Gilbert $v$ Stone may in fact have nothing whatever to do with excuses in tort.

${ }^{51}$ Goudkamp (n 1) 76.
} 
within tort law ${ }^{52}$ does not rule out the possibility that a credible argument in respect of particular excuses could be made, here and there. ${ }^{53}$

In order to assess whether duress may operate as an isolated excuse in tort, then, we may usefully turn for guidance to tort law's civil law sibling, the law of contract. After all, the duress principle is very firmly rooted in that setting; and it would therefore be striking if the law of contract were to take one position while the law of torts took another (at least so long as the same, or equally powerful, reasons in favour of its adoption in tort could be offered). Goldberg agrees, conceding readily that "I would have some explaining to do as to why [we have excuses in contract but not in tort], given the many commonalities between contract and tort". ${ }^{54}$

However, before considering in depth the three possible bases for a duress defence in tort by analogy with contract, it is devoting a little space to some of their commonalities. Two in particular are noteworthy. The first is that, just as in tort cases, the courts must likewise in contract cases treat equally the competing interests of claimant and defendant. Accordingly, it becomes difficult to argue that excuses have no place in tort if they can be shown to exist comfortably in the contract setting. If duress is perfectly at home one private law context, then why not in another?

A second notable commonality can be observed in the pioneering work of Professor Peter Birks who famously set out a series of compelling reasons as to why it would appropriate to treat breaches of contract (at least where specific performance is not sought) as part of the same legal category as torts (ie, wrongs). ${ }^{55}$ This link between torts and breaches of contract - just like the fact that the court has the same competing interests to consider in both cases - tends to suggest a prima facie case for having similar types of defence in both settings.

But before simply rolling out in tort law what we find in contract, an important caveat must also be lodged. It is that any attempt to fashion a duress defence in tort by analogy with contract should be undertaken with some measure of reserve given that it is not at all easy to say just what kind of defence duress is within contract law, or even whether it is right to call it a defence at all. ${ }^{56}$ We must tackle this point before attempting to work out just what kind of a defence duress may be in contract law: an excuse, a justification or a public policy defence?

\footnotetext{
${ }^{52}$ For a summary of, and engagement with, these authors' arguments, see Goudkamp (n 36) 224-231.

${ }^{53} \mathrm{Ibid}, 231$. Carving out such exceptions is no easy matter, however. If there is general resistance to excuses in tort law, there would be a burden to explain why particular excuses should cut against the grain and be recognized.

${ }^{54}$ Goldberg (n 12) 509.

${ }^{55}$ P Birks, "The Concept of a Civil Wrong" in DG Owen (ed), Philosophical Foundations of Tort Law (Oxford: OUP, 1997).

${ }^{56}$ For the general argument that it is hard to pin down quite what a defence is within the law of contract, see $\mathrm{K}$ Barker, "What is a Contractual Defence (and Does it Matter)?" in A Dyson et al (eds), Defences in Contract (Oxford: Hart, 2017).
} 


\section{(a) Is Duress a Defence in Contract Law?}

At least two possible excuses exist in contract law. One is frustration, the other is duress. Only the latter is relevant here; and a tricky preliminary matter to unpick is whether it is actually right to consider duress a defence.

A useful starting point is Professor Smith's monograph on contract theory which examines duress under the chapter heading "Excuses for Non-Performance". ${ }^{57}$ In so treating it, Smith plainly suggests that duress is an excuse (and therefore a defence) in the contract setting. But is this right? Might it not plausibly be thought that duress is a denial: a plea, that is, that an essential ingredient $-i e$, consensual agreement - is absent ${ }^{58}$ There is certainly intuitive appeal in the idea that coercion exerted by the promissee vitiates the promissor's consent (and therefore the agreement element). But despite its appeal, this interpretation of how duress works in contract must be rejected.

Suppose that $\mathrm{X}$ bullies $\mathrm{Y}$ into a contract by holding a gun to his head, saying: "sign on the dotted line or I will kill you". In such a case, as Smith explains, Y can be said to have concluded the contract consensually inasmuch as he had the option of not entering the contract. ${ }^{59}$ Lord Diplock said something similar in his leading speech in The Universe Sentinel. In his view, threats do not indicate an absence of consent, but merely the fact that it has been improperly obtained. He put it this way:

It is not that the party seeking to avoid the contract ... did not know the nature or the precise terms of the contract at the time when he entered into it or did not understand the purpose for which the payment was demanded. The rationale [behind duress is instead that] $\ldots$ his apparent consent was induced by pressure $\ldots$ which the law does not regard as legitimate, with the consequence that the consent is treated in law as revocable. ${ }^{00}$

If this be right, and if duress does not in fact vitiate consent, it may still be considered a denial if the law demands more in terms of contractual agreement than that there was a genuine choice to conclude the contract. If in addition the law insists that such a choice be legitimate (by which I mean made in the presence of reasonable alternatives), then it would still be possible that duress could be invoked as a denial. This would not be because there was no consent given, but because there was no legitimate choice on offer.

\footnotetext{
${ }^{57}$ S Smith, Contract Theory (Oxford: OUP, 2004) ch 9.

58 Goldberg, (n 31 ) 170.

${ }^{59}$ Smith (n 57) 331.

${ }^{60}$ [1993] 1 AC 336, at 384 per Lord Diplock. See also, PS Atiyah, "Economic Duress and the Overborne Will" (1982) 98 LQR 197.
} 
So does contract law demand that consent be given by a person faced with reasonable alternatives? It is submitted that it does not; and for two reasons. The first is grounded on legalphilosophical considerations; the second is rooted in established case law.

In a duress scenario, the threat-maker, $\mathrm{X}$, seeks to manipulate Y's rationality. He exploits the fact that he knows that $\mathrm{Y}$ will chose to make an unfavourable contract rather than get shot. Accordingly, when $\mathrm{Y}$ signs the contract, he does so acting rationally. This means that $\mathrm{Y}$ meets the widely accepted conditions of basic responsibility in private law. He was aware of his conduct; he engaged in it for a reason; and he was actually or constructively aware of its possible consequences. ${ }^{61}$ His acting in a way that meets these conditions supplies a philosophically satisfying reason for treating the choice that he makes as one that ought to bind him.

The second reason why we should reject the idea that contract law ignores consent given in the absence of reasonable alternatives is rooted in case law which establishes that contracts made under duress are voidable. Voidable contracts are valid contracts until they are set aside. In the passage cited above, Lord Diplock made clear that contracts made under duress are "revocable". Since one cannot revoke a nullity, we are forced to conclude that consent given in the absence of reasonable alternatives is binding and that, consequently, a plea of duress cannot function as a denial. Such a plea is a defence in that it exonerates a defendant from his refusal to perform his side of a valid contract. ${ }^{62}$ So, for all that duress plays an increasingly minor role in the modern law of contract, ${ }^{63}$ all that remains to be done here is (1) work out just what kind of defence duress actually is in this context, and (2) explore whether a similar defence could be created in tort law by analogy.

\section{(b) Duress as an Excuse in Contract (and Tort by Analogy)}

In contract, when a duress victim refuses to honour his side of a bargain, but nonetheless claims that he should not be held liable for breach, he conceivably invokes duress as an excuse. His decision not to perform his side of the contract is rational, but not fully warranted insofar as he is, as we have already noted, validly bound himself to do so. If this be the right conception of duress in contract, we must not be too hasty in assuming that duress could operate likewise within tort. After all, despite the commonalities adverted to earlier, there remain some important

\footnotetext{
${ }^{61}$ For this iteration of basic responsibility and details of, and engagement with, others that are practically identical, see W Lucy, Pbilosophy of Private Law (Oxford: OUP, 2007) ch 3.

${ }^{62}$ In saying this I adopt Goudkamp's definition of a defence as being any rule of law "that relieves the defendant of liability even though all the elements [necessary to ground an action] are present": Goudkamp, (n 1) 7.

${ }^{63}$ Duress is of greatly diminished modern usage since most commercial contracts are made, not by actual persons, but by legal persons. It is plainly nonsense to talk of putting a gun to the head of a company. At the same time, however, it is fair to observe that, much as they may enjoy lesser usage these days, the cases that unearthed the duress rationale are still authorities in the strict sense.
} 
differences between these two branches of the law. One such difference may be observed in the following.

Where, by virtue of A's duress, B is coerced into making a contract with $A$, there is an obvious moral mismatch between A and B. A, is very obviously morally tainted while $\mathrm{B}$, the victim of that duress, will have a much lesser moral stain. In a tort case such as Gilbert v Stone, however, things are very different. This is because such situation will involve a third person whose involvement tends to deepen the moral stain upon the person seeking to invoke a defence of duress.

A typical tort scenario might involve $\mathrm{X}$, under duress from $\mathrm{Y}$, committing a tort against $\mathrm{Z}$ and then seeking to rely upon a defence of duress. In such a situation, $\mathrm{X}$ is nowhere near as close to moral innocence as $\mathrm{B}$ in the contract example. This is because $\mathrm{X}$ will have made the conscious choice (when threatened by $\mathrm{Y}$ ) to inflict harm on $\mathrm{Z}$ rather than himself suffer the injury or loss that $\mathrm{Y}$ threatened to inflict. Some might describe $\mathrm{X}$ as a coward: a person who would rather see another suffer than himself face the prospect of injury or loss. But if the harm that he causes fairly minor loss to $\mathrm{Z}$, and was threatened with something very grave indeed by $\mathrm{Y}$, it need not be seen this way. One could very well argue that, in such circumstances, X's election to harm $\mathrm{Z}$ was a rationale and understandable decision. The net loss would certainly be lower if $\mathrm{X}$ were to visit upon $\mathrm{Z}$ harm of a lesser kind than that with which he himself threatened by $\mathrm{Y}$. So an ostensible case for an excuse can be made. But it is by no means a conclusive case and the analogy can at best be drawn with caution. Whereas in contract the illegitimacy of the pressure brought to bear by the person making the threat is key, ${ }^{64}$ in tort, the severity and illegitimacy of the threat made is merely one consideration to be borne in mind. The nature of the tort committed by $\mathrm{X}$, as well as the fact that $\mathrm{X}$ seeks preserve his own well-being at the expense of $\mathrm{Z}$ must always also be considered and these factors tend to push against the development of a duress defence in tort.

So is it, ultimately, appropriate to create a duress defence in tort by analogy with contract when it is clear that tortfeasor will always bear a significant moral taint? One possible reason for thinking that it would be alright is that allowing such a defence would help maintain the coherence of tort law. In the context of nuisance law, it was established in Southport Corporation v Esso Petroleum that a defence of public necessity will be available if $\mathrm{X}$ deliberately commits a tort against $\mathrm{Y}$ where the emergency that $\mathrm{X}$ attempts to deal with has arisen without fault on X's part. ${ }^{65}$ Notably, in any such, $\mathrm{X}$ is again faced with an unenviable choice. In electing to commit a tort against $\mathrm{Y}$ for the greater good, $\mathrm{X}$ is only again tainted. But nuisance law disregards this

${ }^{64}$ The Universe Sentinel [1993] 1 AC 336, at 384 per Lord Diplock.

65 Southport Corporation v Esso Petroleum Ltd [1956] AC 218, 242. 
moral taint and allows the defence. In the interests of coherence, then, it might be argued that the same approach should be taken with respect to the defendant's moral taint in a case like Gilbert v Stone or the hypothetical above involving X, Y and Z.

A second response to the suggestion that we should hesitate before making duress an excuse in tort law by analogy with contract stems from the observation that even in three party cases of contractual duress - that is, cases in which A compels B to enter into a contract with C (without any collusion or knowledge on C's part) - the courts of New York "generally consider duress a valid ground for rescission despite the innocence of the other party [ie, C]". ${ }^{66}$ Again the intermediary puts his own interests first, and seeks to foist the ultimate harm (caused by the intermediary's subsequent refusal to perform) upon an innocent third party. The courts of New York allow him to do so. We could therefore seek to draw our analogy with these three-party contract cases wherein a morally tainted individual is nonetheless permitted to rely on a defence of duress.

A third response might be to look to three-party cases of undue influence for guidance. This branch of the law might be thought instructive insofar as it shows the courts' preparedness to entertain a plea of undue influence even where the influence in question was brought to bear upon an intermediary whose position is "open to some justifiable criticisms". ${ }^{67}$ One might again argue on the back of such cases that, if "mere" undue influence upon a third party who is not without moral stain can be excused, then should be a tortfeasor who, with similar moral stain, was been subjected to an outright threat (rather than "mere" undue influence).

Each one of these responses has something going for it. But none is entirely watertight. One could contend, for example, that coherence in tort law could be achieved by taking the opposite course: that is, by divesting defendants of a public necessity in cases like Esso Petroleum. Equally, one might raise the objection that none of the New York duress cases, and none of the English undue influence cases, really establishes that an excuse of duress should or would be recognised in a three-party English contract case (were one ever to arise). New York cases are, at most, persuasive; and undue influence (in equity), one may say, is a significantly different beast from common law duress. So, in the absence of any three-party duress cases in English contract law, perhaps the most we can say is that there is some - but admittedly limited - scope for constructing a duress defence in tort by analogy with contract.

\footnotetext{
${ }^{66}$ Anon, "Duress of a Third Person as Grounds for Rescission of a Legal Transaction" (1930) 5 Columbia L Rev 714, 720. There are, so far as I could detect, no reported English cases of this three-party variety.

${ }^{67}$ Cresswell v Potter [1978] 1 WLR 255, 260 per Megarry J.
} 


\section{(c) Duress as a Justification in Contract (and Tort by Analogy)}

As noted earlier, one pressure point in Goldberg's attempt to rebut the Edelman and Dyer thesis is the fact that he fails to make clear exactly why duress should be seen as an excuse. His rejection of their position, it will be recalled, relies ultimately on the claim that torts are inexcusable. His unwillingness to accept duress as a tort defence is therefore based on the mere assumption that, if it were introduced, it would function as an excuse. (His assumption seems to be based on the fact that duress is an excuse within the criminal law which is, at the very least, ironic given the way he elsewhere cautions us about making legal transplants from criminal law to private law.)

The idea explored in both this and the next section is that duress might conceivably operate as something other than an excuse in contract. The driving thought is that, if a plausible alternative conception of duress is available, this might not only support the analogical development of an equivalent defence in tort, but also render nugatory Goldberg's arguments against excuses. It will allow us to leave to one side the possibly barren soil of excuses and consider whether duress in contract and tort could be conceived as either a justification, or a public policy defence. We begin with the first of these.

Although a clear-cut, theoretical distinction between excuses and justifications can be drawn with relative ease, it is nonetheless a distinction that is sometimes hard to draw in practice. This is especially the case with duress. Suppose, for example, that A forces B to enter into a contract with A. Suppose, too, that although it was highly unattractive, B did have the option of not entering into the agreement and suffering in whatever way A threatened. In such a case, we already know that B's consent is valid. Yet a court might well regard B's subsequent decision not to honour the contract as having been justified vis à vis A. ${ }^{68}$ It might even hold - though this is not strictly necessary - that B's decision not to fulfil his contractual duties was more than merely reasonable; that it was in fact commendable since $\mathrm{D}$ could be said to be fighting back against the bully.

If this is correct, and duress works (at least sometimes) as a justification in contract, might it also operate this way in tort law? Are there at least some circumstances in the tort setting where a court might form the view that the reasons given to explain D's conduct are considered strong enough to justify that conduct? The answer seems to be "Yes", at least according to several jurists and philosophers who have considered the matter. ${ }^{69}$

\footnotetext{
${ }^{68}$ That D's act might be regarded as justified in general terms is, strictly, neither here nor there. D's having acted commendably merely shows that he acted in a way that was right in the eyes of the world. But as Vincent (n 47) illustrates, it is possible to act in a way that is simultaneously right (in the eyes of the world) yet wrong (vis a vis the victim's rights).

${ }^{69}$ See, eg, JF Stephen, A History of the Criminal Law in England (London: Macmillan, 1883) 109; Edelman and Dyer (n 10) 179.
} 
The classic kind of case would involve D choosing a course of conduct that represents the lesser of two evils. Kent Greenawalt has provided a helpful hypothetical in this connection.

If Fred remains completely cool while he steals a diamond in response to a credible threat that three strangers will be killed if he refuses, his action falls within the defense. Here, Fred's choice is the best under the circumstances and is morally justified... [But, if Fred were] to sacrifice greater interests for lesser ones, duress would be offered as an excuse. ${ }^{70}$

Although it is easy to see why a court in a situation like this would probably consider D's conduct (both a crime and a tort) to be justified, one possible objection to my invocation of Greenawalt's hypothetical is that D's conduct might more accurately be described in terms of public necessity, an extant defence in tort law that stands apart from duress. If that be thought fair criticism, then the hypothetical must be tweaked in order to eliminate this possibility. If Fred, for example, were told that he must steal the diamond or himself be shot, then the situation would clearly be one in which talk of his acting under duress would be appropriate, but talk of public necessity would be misplaced since only Fred's interests would be at stake.

On this reformulated hypothetical, it seems pretty clear that duress could conceivably operate as either an excuse or a justification depending on whether the lesser of two evils principle is in play. ${ }^{71}$

At this point the sceptic might say: "Fair enough. But in making this argument, any sense of a true analogy with contract law is lost because duress in contract can never be analysed in terms of the lesser of two evils". That is true insofar as a duress plea in contract is only ever raised after the threat which led to the contract being made has already expired. The threat in such cases expires the minute the contract is made. At precisely this point, the threat-maker gets what he wants and the threat expires. So when a threatened party subsequently raises a plea of duress, he is no sense choosing between two evils. This is not, however, a fatal objection to the drawing of analogy, since it misses the critical point.

I am not seeking to argue that duress could apply identically in the contract and tort settings; merely that its operation within contract law can plausibly be used to assist us in developing an equivalent type of defence in tort. If we have a basis for thinking that duress may operate as a justification within contract, we may usefully invoke this conception of duress when

\footnotetext{
${ }^{70}$ Greenawalt (n 7) 1912. Though Greenawalt's example is designed to explain the criminal law, the same point can be made regarding tort law (albeit in the latter context one would have to factor into the calculus not just Fred's wrongdoing and the lives of the potential murder victims but also the rights of the diamond owner).

${ }^{71}$ Cf Goldberg (n 31) 480 who seems to entertain the idea that only the defence of self-defence could be considered either a justification or an excuse depending on whether the lesser of two evils principle was in play.
} 
seeking to fashion a duress defence within tort. The claim, put more simply, is this: if there is room for a justificatory defence of duress within contract law, then there may also be room for a justificatory defence of duress within tort. What we are looking for, then, is means by which acts done under duress can be conceived of as having been justified. It matters not that in contract the justification inheres in the fact that one party is fighting back against a coercive second party, while in tort it stems from choosing the lesser of two evils.

\section{(d) Duress as Public Policy Defence in Contract (and Tort by Analogy)}

There are at least two plausible bases on which one could construct the argument that duress constitutes a public policy defence in contract. The first is the freedom of contract principle or, more accurately, the underlying rationale for that principle. The second is a separate principle found throughout private law: one which states that the courts will not tolerate wrongdoers profiting from their own wrongdoing.

Freedom of contract necessarily entails freedom of choice. It facilitates our ability to pursue purposive and rewarding projects and thereby contributes to the efficient functioning of markets. This, for some scholars, is to be applauded since it helps to achieve what for them is the overall goal of wealth maximisation. Contracts made under duress undermine this efficiency. As Richard Posner explains:

[E]xtortionate threats ... are intended to transfer wealth from the person threatened to the threatener. Such a transfer does not, on its face anyway, increase the social wealth [because it is not the case that both parties consider themselves better off for the bargain]; and indirectly it diminishes it by the sum of the resources employed by the threatener to make his threat credible and of the victim to resist the threat. ${ }^{72}$

Conceived in these terms, the duress defence has a clear public policy footing: ${ }^{73}$ the efficiency (or, utility) rationale that, for many jurists, underpins the freedom of contract principle. ${ }^{74}$ In their eyes, contracts voluntarily entered into are efficient simply by virtue of being voluntarily entered into. Both parties are content to conclude the contract because, for each of them, the perceived

\footnotetext{
${ }^{72}$ RA Posner, "Blackmail, Privacy and Freedom of Contract" (1993) 141 U Penn LR 1817, 1820-21

${ }^{73}$ Note that although the idea of a public policy defence has been used by Goudkamp, he employs the term in a slightly more conservative way: see Goudkamp (n 1) 76.

${ }^{74}$ It could be argued that freedom of contract is an essential aspect of contract formation and that, insofar as duress denudes a contract of this, a plea of duress can be raised as a denial. The argument fails, however, because a denial serves to place in question the idea that a valid contract ever existed. This line of thought was shown to be untenable above.
} 
benefits outweigh the costs. As such, there is a net gain in overall wealth when contracts are made freely. By contrast, there is a net loss where contracts are concluded under duress. ${ }^{75}$

An alternative public policy basis for the duress defence in contract - and the one in fact favoured by Smith (although he makes the mistake of labelling the defence an excuse ${ }^{76}$ ) - is one that can be cashed out in terms of the illegality rule which runs right throughout private law. It is a rule grounded in the policy that the "courts will refuse to assist wrongdoers who wish to obtain the profits of their wrongdoing". ${ }^{77}$

If either of these public policy explanations of the duress defence in contract is sound, then there may be room for the argument that, by analogy with contract, a public policy defence of duress could be established in tort. Of course, an immediate and obvious objection to this suggestion is that public policy has no legitimate role to play in the law of torts. Both Kantians and rights theorists have argued powerfully, and at great length, to this effect. ${ }^{78}$ However, against their objections - which are putatively based on tort law as it presently exists rather than as they would prefer it to be - it may be noted that a sizeable array of public policy defences already exist. Limitations of actions and res judicata, for example, are both designed to ensure the smooth running of the legal system, while the Parliamentary privilege defence is keyed to the objective of facilitating the proper functioning of Parliament. Accordingly, however powerfully one may argue against policy based rules of tort law, it is important to recognize that such arguments are entirely normative ${ }^{79}$ and amount to no more than one view of how the law of torts ought to be. The reality about tort law as it presently stands is that - for good or ill - there are many existing rules and doctrines that are anchored to public policy considerations. Put simply, there is nothing inherent in the present state of tort law that stands obdurately in the way of a public policy based defence of duress.

So what might a public policy basis for duress in tort look like? One possibility is that it could be grounded in a desire for administrative efficiency in the justice system. If a plea of duress were permissible in case like Gilbert v Stone, its availability to the intermediary would force the claimant to seek his remedy (under the tort of causing loss by unlawful means) from the

\footnotetext{
75 One caveat here is that this account will not appeal to everyone, drawn, as it is, from the law and economics canon.

${ }^{76} \mathrm{He}$ asserts unequivocally that "duress is a true excuse doctrine": Smith (n 57) 318. Yet he overlooks the fact that excuses look to the reasons given by $\mathrm{D}$ for his impugned conduct whereas a defence based on the law's concern not to allow wrongdoers to profit by their own wrongdoing looks primarily to C's unlawful conduct.

77 Smith (n 57) 321. What this explanation of duress in contract fails to capture, however, is the small group of cases in which $\mathrm{C}$ seeks to take advantage of a threat made to D by a third party. Here, D's plea of duress is not designed to deny $\mathrm{C}$ the prospect of profiting from his own wrongdoing. It is an interesting question how best to explain such cases, but it is one for another day.

${ }^{78}$ See, eg, EJ Weinrib (n 82) ch 1; R Stevens, Torts and Rights (Oxford: OUP, 2007) ch 14.

79 See J Goudkamp and J Murphy, "Tort Statutes and Tort Theories" (2015) 131 LQR 133; id, "The Failure of Universal Theories of Tort Law" (2016) 22 Legal Theory 47.
} 
maker of the threat rather than the victim of the threat. Requiring the claimant to bring his claim against the threat-maker would save the intermediary any involvement in needlessly complex proceedings involving joint defendants from which that intermediary would emerge free of any liability. Granting the intermediary this defence would also eschew the prospect of him being successfully sued, then having to recoup the damages from the threat-maker in subsequent indemnity proceedings. Either way, we can be reasonably confident that it would be the threatmaker who would ultimately pick up the bill for damages. However, if the question of contribution between the threat-maker and his victim were to arise, it is well established that where the relative culpability of $\mathrm{D}_{1}$ and $\mathrm{D}_{2}$ is very obviously skewed, "no court would think it just and reasonable that [the threat victim, $\mathrm{D}_{1}$ ] .. should be ordered to make a contribution". 80 In short, granting the intermediary a duress defence in a case like Gilbert $v$ Stone would help streamline the administration of justice by avoiding his needless inclusion in litigation.

There is a possible snag here, though. It is that public policy considerations might not be thought to point in a single direction. Let's suppose that D is bankrupt, or that he has disappeared and cannot be found. In such circumstances, it might be thought preferable - as between the claimant, $\mathrm{C}$, and the threat victim, $\mathrm{V}$ - that $\mathrm{C}$ should be entitled to sue $\mathrm{V}$ so that $\mathrm{V}$ should become the ultimate bearer of the loss. Why, we might ask, should C bear the risk of D's bankruptcy or disappearance when - as between C and V - only C is completely morally blameless? True, $\mathrm{V}$ can claim to be innocent in one sense: he acted under duress. But he also consciously elected to save his own skin at C's expense and is therefore carries some moral taint. With this in mind, ought not public policy to dictate that we should favour the "more innocent" of the two so that, if at all possible, $\mathrm{C}$ (who is entirely innocent) will receive proper compensation? The answer is by no means obvious, not least because the contest is ultimately between incommensurable policy values. There is a rough and ready judgment to be made about which is the more worthy, the pursuit of administrative efficiency or the guarantee of compensation for the completely innocent.

While no definitive answer can be given in this regard, there are at least two further observations that might be thought to support the granting of a duress defence. First, we could advert to the fact that giving $\mathrm{V}$ a defence would usefully add to the deterrent value of tort law. If $\mathrm{V}$ had such a defence, $\mathrm{D}$ would never be in a position to think: "If I can get $\mathrm{V}$ to do my bidding in harming C, I might escape liability myself by making V the target of C's ensuing litigation". That being so, $\mathrm{D}$ might well conclude that it would be a bad idea, all things considered, to coerce $\mathrm{V}$ into harming $\mathrm{C}$.

${ }^{80}$ African Strategic Investment (Holdings) Ltd v Main [2011] EWHC 2223, at [47] per Barnard Livesey QC. 
A second point to bear in mind is that tort law rarely, if ever, seeks strenuously to ensure that tort victims get compensation. Much as it is frequently touted as such, the "deep-pockets of the employer" explanation of vicarious liability fails to explain or justify that principle. ${ }^{81}$ Against this background, one might fairly (though tentatively) conclude that the more intuitively compelling (though technically not weightier) policy arguments lie in favour of the creation of a duress defence in tort.

\section{(5) Conclusion}

Edelman and Dyer made a spirited initial attempt to advance the idea that tort law should welcome a defence of duress. John Goldberg later countered the case that they made - in some respects convincingly, in others less persuasively. The thrust of Goldberg's argument was that duress and all other defences falling within the category "excuses" have no place in tort law. For the reasons given in Section 3, I have departed from both schools of thought and instead ploughed a very different furrow. I have suggested, by contrast with Edelman and Dyer (who rely on an analogy with crime, and a link with a putative defence of private necessity) an altogether different starting point in answering the central question. I favoured the possibility of drawing guidance from the role of duress in contract on the footing that there exists a much closer link between contract and tort than exists between criminal law and tort.

In particular, I was driven by the thought that there should be (where possible) coherence within private law. ${ }^{82}$ Noting that a duress defence is alive and well in the contract setting, I examined various cases for creating an equivalent defence in tort law by analogy. The attempt to draw such as analogy was complicated by the fact that it is not entirely clear whether duress works as an excuse, a justification or a public policy defence in contract. I therefore took each possible conception in turn, and explored the possibility of creating a duress defence in tort on broadly comparable grounds. Without fully nailing my colours to the mast as regards the role of duress in contract, I showed that all three conceptions could plausibly ${ }^{83}$ be used to ground the analogical development of a duress defence in tort. Yet, because of my ambivalence about the nature of a duress defence in contract, I also stopped short of saying how duress should function it tort law. I ventured nothing more than the plausibility of it functioning as a either justification, or an excuse or a public policy defence.

\footnotetext{
81 See J Neyers, "A Theory of Vicarious Liability" (2005) 43 Alberta L Rev 1, 6-7; PS Atiyah, Vicarious Liability in the Law of Torts (London: Butterworths, 1967) p 22.

82 For one version of this argument, see EJ Weinrib, The Idea of Private Law (Cambridge, MA: Harvard University Press, 1995) ch 1.

${ }^{83}$ I remain conscious of the fact that there many ways in which tort and contract come apart; so I claim no more than a strong prima facie case for analogical development based on the commonalities adverted to earlier.
} 
Though my ambitions in this article have been have been principally theoretical (or at least exploratory), it is perhaps worth making an additional point or two about practicalities. The first point worth adding concerns the everyday usefulness of duress in tort. Thus far we have undoubtedly muddled along without one. It might fairly be asked, then, whether tort law would be any the ricer if we created one. The answer is "Yes". A duress defence in tort could fulfil a significant role in cases of civil conspiracy where one conspirator alleges that he was forced to act in the way that he did by his co-conspirators. ${ }^{84}$ It is certainly noteworthy that pleas of duress in such circumstances are reasonably common in the criminal law context. If such a plea were available in tort, it would doubtless be raised in such circumstances. A second use for duress in tort would arise in cases of causing loss by unlawful means (where the defendant has been intimidated by a third party into causing loss to the claimant and the third party has since disappeared - as in Gilbert v Stone - or subsequently become insolvent).

A separate practical point concerns the way in which the defence could best be created. Should it be wrought by statute, or by incremental development of the common law? This is an important question that follows naturally from the central question with which this article has grappled. However, it is a distinct question that for reasons of space cannot be tackled fully here. It must suffice, therefore, to suggest tentatively that the change could best be made by the courts. In part this is because it would amount to just the kind of incremental development we readily associate with the courts: a novel, but hardly, radical change in the law. ${ }^{85}$ In addition it would likely be seen as a civil law reform for which Parliamentary time would be unlikely to be found.

\footnotetext{
84 A Westlaw search revealed 6 such cases reported in 2017 alone. See, eg, R v Aghayere [2017] EWCA Crim 692 and $\underline{\mathrm{R} v \text { Babiak [2017] EWCA Crim } 160 .}$ 85 For a similar (undefended) view that the courts could make the change, see Edelman and Dyer (n 10) 182.
} 